\title{
A CONCEPÇÃO SOCIALISTA DE EDUCAÇÃO POLITÉCNICA: CONTRIBUIÇỖES DOS SOCIALISTAS UTÓPICOS, LIBERTÁRIOS E CIENTÍFICOS
}

Vitor Bemvindo ${ }^{1}$

\begin{abstract}
RESUMO
É comum observar, nos trabalhos sobre educação politécnica, essa concepção educativa ligada às contribuições de Marx e Engels. Alguns autores chegam até definir politecnia como um sinônimo de educação marxista. Essas análises ignoram, no entanto, a história de apropriação do conceito, que se inicia na transição do século XVIII para o XIX, quando a burguesia toma o poder na França e inaugura as primeiras escolas com a denominação "politécnica". Estas escolas foram marcadas por um modelo fortemente orientado pelo positivismo e pela necessidade de se criar uma elite tecnocrática capaz de dirigir o processo produtivo, mas também o político. No campo da crítica às concepções burguesas, as primeiras reflexões sobre a articulação entre trabalho e educação são subsidiárias dos socialistas utópicos. Pouco depois essas reflexões foram aprofundadas pelos socialistas libertários, ou anarquistas, responsáveis pelas discussões sobre educação integral e politécnica. O presente artigo defende que as reflexões de Marx e Engels sobre o tema são subsidiárias das contribuições tanto de socialistas utópicos quanto de anarquistas.
\end{abstract}

Palavras-chave: Educação Politécnica; Trabalho e Educação; Politecnia.

\begin{abstract}
It is common to notice in the works about polytechnic education to observe this educational conception linked to the contributions of Marx and Engels. Some authors even define polytechnic education as a synonym for marxist education. These analyzes, however, ignore the history of appropriation of the concept, which begins in the transition from the XVIII to the XIX century, when the bourgeoisie takes power in France and inaugurates the first schools with the name "polytechnic". These schools were marked by a model strongly oriented by positivism and by the need to create a technocratic elite able to directing the productive process, but also the political one. In the field of criticism of bourgeois conceptions, the first reflections on the articulation between work and education are subsidiaries of the utopian socialists. Shortly afterwards these reflections were deepened by libertarian socialists, or anarchists, responsible for discussions on integral and polytechnic education. The present article argues that the reflections of Marx and Engels on the subject are subsidiary of the contributions of both utopian and anarchist socialists.
\end{abstract}

Keywords: Polytechnic Education; Labor and Education; Polytechnic. 
Um elemento da luta de classes que talvez não tenha sido observado por historiadores com a devida atenção é a disputa pelas palavras, pelos conceitos. A construção do vocabulário das diversas classes e frações de classes também é fruto de uma disputa por hegemonia, sendo que certas palavras ou conceitos acabam se tornando chave para a construção da própria luta entre projetos societários.

Entre as palavras disputadas, talvez a mais reivindicada por grupos distintos tenha sido democracia. Se olharmos para a história veremos uma grande diversidade de grupos ou classes sociais que, em diferentes momentos históricos, reivindicaram para si o termo democracia, cada um deles lhe aplicando uma concepção distinta, obviamente adequada à ideologia do projeto societário por eles defendido. A elite escravista ateniense, as oligarquias da República Romana, os déspotas esclarecidos, as burguesias revolucionárias francesas e inglesas dos séculos XVIII e XIX, as organizações dos trabalhadores contra as opressões advindas das transformações da Revolução Industrial, os regimes liberais e até mesmo os fascismos; todos, em algum momento, reivindicaram para si a democracia. É evidente que cada um desses grupos atribuiu a essa palavra o sentido e o conteúdo que lhe pareceu conveniente a determinado projeto de sociedade e momento histórico. Esse movimento de disputa pode ser observado em relação outros termos como: trabalho, revolução, golpe, solidariedade, justiça, igualdade, sustentabilidade, entre inúmeras outras.

Mikhail Bakhtin, em seus estudos sobre a linguagem, dedicou-se a compreender como as relações de produção impactam na construção das palavras e as dão significados e conteúdo. Para ele, "a palavra está sempre carregada de um conteúdo ou de um sentido ideológico ou vivencial" (BAKHTIN, 2006, p. 95). É a partir dessa premissa que analisaremos, ao longo deste artigo, como distintos grupos sociais (ou frações de classe) se apropriaram do conceito de politecnia ou educação politécnica. No entanto, o que se pretende é fazer uma análise histórica e não de caráter linguístico ou filológico. O que nos interessa é como as transformações das forças produtivas, ao longo da história, influenciaram esses grupos a entenderem a politecnia ou educação politécnica como um elemento importante para a construção de ideologia e de projetos societários.

Partimos, então, do princípio de que essas diferentes concepções de politecnia estão "contaminadas" pelas visões de mundo de cada um desses grupos, tal qual salienta José Carlos Souza Araújo:

as visões de mundo têm nas concepções educativas um significativo ancoradouro, pois estruturam-se vinculadas a concepções antropológicas: estão implícitas nessas, entre outras, posturas a respeito da história, da moral, da sociedade, da política, da economia, da existência, da cultura, do trabalho, enfim, essas são dimensões que expressam o ser do homem (ARAÚJO, 2008, p. 41). (grifo nosso)

Araújo toma como base para essa afirmação as ideias de LucienGoldmann. Para o sociólogo francês "as visões de mundo são a expressão psíquica da relação entre certos grupos humanos e seu meio social e natural e seu número é, pelo menos para um longo período histórico, necessariamente limitado". (GOLDMANN apud ARAÚJO, 2008, p. 42). Mas o primordial da análise de Araújo, é entender a importância das concepções educativas como "significativo ancoradouro". Ou seja, compreender essas concepções de educação é apreender parte fundamental das construções ideológicas de determinado projeto societário.

Essas concepções, como afirma Araújo, são síntese de múltiplas determinações. Como seria exaustivo - tanto para quem escreve, quanto para quem lê - analisar todos os elementos contidos nas concepções educativas que serão analisadas, atentaremos em especial para a relação entre trabalho e educação. Faremos assim, por entendemos que, 
independentemente do projeto de sociedade defendido pelo sujeito que se apropria do termo politecnia, este sempre foi utilizado para fazer alguma relação entre processos educativos e processos produtivos. O que diferenciará cada uma dessas concepções é, principalmente, o entendimento que cada um desses grupos tem sobre o trabalho. No entanto, as dimensões política, social, moral, econômica, cultural e até existencial não serão ignoradas, apenas não serão o centro da análise aqui proposta. Porém, acreditamos que ao dar destaque às dimensões do trabalho, de forma indireta observamos as demais determinações.

Desta forma, coincidimos com a análise de Lúcia Neves que, baseada em Gramsci, Poulantzas e Coutinho, afirma que:

[...] de um modo geral, a política educacional em uma determinada formação social concreta, no mundo contemporâneo, é determinada pelo estágio de desenvolvimento das forças produtivas e das relações de produção e, também, pelo embate provisório das várias propostas educacionais em disputa pela hegemonia do Estado, em sentido estrito, e na sociedade civil (NEVES, 2007, p. 208).

É a partir dessa perspectiva, a do "embate de propostas educacionais" é que analisamos a disputa por hegemonia em torno ao termo politecnia e à relação trabalho e educação. Ao longo da tese "Por uma História da Educação Politécnica: Concepções, Experiências e Perspectivas" (BEMVINDO, 2016), analisamos as diversas apropriações do conceito de politecnia para compreender como se dá, no campo da educação, a disputa entre diversas propostas educacionais marcadas por diferentes projetos societários, também em disputa. Na análise proposta na tese, partimos da perspectiva de que a concepção de educação politécnica foi gerida dentro do campo da pedagogia burguesa, sendo mais tarde reapropriada criticamente por grupos que disputavam a hegemonia no campo educacional. Essa perspectiva supera a ideia de que o conceito de educação politécnica esteve associado historicamente ao campo do socialismo científico, ao materialismo histórico e dialético, como defende, por exemplo, José Rodrigues: "o conceito de 'educação politécnica' foi esboçado inicialmente por Karl Marx, em meados do século XIX. Em outras palavras, 'educação politécnica' pode ser vista como sinônimo de concepção marxista de educação" (RODRIGUES, 2009).

Partimos da constatação de que as primeiras escolas com a denominação politécnica surgiram após os eventos da Revolução Francesa, que consolidaram a burguesia como classe hegemônica, política e economicamente, na França e, mais tarde, em toda a Europa. A primeira dessas escolas, a École Polytechnique (Escola Politécnica de Paris), foi fundada em $1794^{2}$, e em 1805 recebe tal denominação de Napoleão Bonaparte, e possuía um modelo educativo bem definido e que foram replicados em diversas escolas do mesmo tipo não só na Europa, como também no Brasil. Não à toa, em diversos casos, é comum notar a denominação "politécnica" às escolas de nível superior de engenharia. $\mathrm{Na}$ tese supracitada, defendemos que mais do que apenas uma denominação, as escolas que envergam o nome "politécnica" trazem consigo um modelo educacional claramente definido, cujas principais características são: (1) formação utilitária para o trabalho produtivo e marcada pelo positivismo combinada à formação intelectual geral sob base dos elementos culturais da ideologia burguesa, (2) formação de quadros políticos capazes de dirigir o processo produtivo e ocupar posições políticas e tecnocráticas no Estado e (3) restrição de acesso às classes populares. Assim sendo, pode-se dizer que nessa concepção de politecnia há a preocupação de integrar a formação (de nível superior) específica para o trabalho (e o desenvolvimento das forças produtivas na França pós-revolucionária) à formação de cultura geral visando à constituição dentro da classe burguesa de uma fração 
tecnocrática. Portanto há, nas escolas politécnicas burguesas, a constituição de um modelo educativo que combina a formação de especialistas técnico-científicos (característico das engenharias) a um enciclopedismo. Defendemos, também, que essa caracterização da concepção burguesa de politecnia - feita através da análise da história dessas instituições não só na França, mas também na transposição do chamado "modelo politécnico francês" para o Brasil - influenciou a formação de escolas de engenharia como as Escolas Politécnicas de São Paulo e do Rio de Janeiro, hoje incorporadas à Universidade de São Paulo e à Universidade Federal do Rio de Janeiro, respectivamente (BEMVINDO, 2016, p. 43-60).

Neste artigo, porém, o que nos interessa de forma mais objetiva é entender como o campo político contra-hegemônico se apropriou desta denominação, "educação politécnica", para constituir um dos elementos centrais da concepção socialista de educação. Mais uma vez, pretendemos superar a visão consolidada na historiografia de que educação politécnica é sinônimo de educação marxista, através de uma (re)construção histórica do conceito, dando especial atenção às contribuições dos socialistas utópicos e libertários (anarquistas) na elaboração dessa concepção educativa. Veremos que muitas das ideias amplamente atribuídas ao campo marxista, já haviam sido discutidas por outros campos da crítica ao pensamento burguês, de forma bastante completa. Defendemos, então, que a concepção marxista de educação politécnica é subsidiária das elaborações dos socialistas utópicos e dos anarquistas.

A pesquisa procurou, sempre que possível, buscar o entendimento da apropriação do termo politecnia, para cada grupo social (ou fração de classe), através da análise de fontes primárias. No entanto, há escasso material traduzido em português sobre as práxis educativas dos socialistas utópicos e libertários, objetos mais específicos deste artigo, sendo a pesquisa complementada por obras de referência sobre o tema.

Após a caracterização das concepções de educação politécnica feitas por socialistas utópicos e libertários, pretende-se compreender os elementos de apropriação e afastamento utilizados por Marx e Engels para a construção de suas concepções educativas, em especial no referente à politecnia. Para isso, nos valemos das elaborações feitas pelos próprios autores fundadores do materialismo histórico e dialético, sobre as quais se pode observar as possíveis adesões e reprovações que ambos tinham às ideias pedagógicas dos seus companheiros anarquistas e utópicos.

\section{Socialistas utópicos e libertários e suas concepções de politecnia}

Antes mesmo de Marx e sua crítica à economia política, outros autores já se colocavam contrários ao modo de produção capitalista, à divisão social do trabalho e à consequente dualidade estrutural por ela imposta à educação das classes burguesa e trabalhadora. Os socialistas utópicos foram os primeiros a se deter à crítica ao caráter classista da educação burguesa. O pioneiro entre os utópicos a se dedicar ao tema foi SaintSimon $^{3}$. Adepto de uma ideologia industrialista, o filósofo francês foi um dos primeiros pensadores europeus a identificar na divisão social do trabalho algo nocivo, voltando-se contra os privilégios sociais. Diante dessa contradição da sociedade industrial, Saint-Simon vê na educação um elemento de emancipação da classe trabalhadora, através da qual seria possível o desenvolvimento de todas as potencialidades e vocações do ser humano, sendo possível, portanto, atingir novas formas de produzir e outra organização da sociedade. Saint-Simon defendia uma educação como prática de relações sociais, e critica o ensino de seu tempo por estar distante da realidade objetiva. Charles Fourier, apesar de não ter a mesma percepção crítica de seu contemporâneo e sendo conterrâneo de Saint-Simon sobre a questão da divisão social do trabalho, também defendia uma educação mais próxima do 
mundo real, de caráter prático, e atendendo as individualidades dos estudantes (MACHADO, 1989, p. 51).

Porém, entre os utópicos, no entanto, foi Robert Owen quem trouxe maiores contribuições para o campo educacional socialista.

Robert Owen (1771-1858) tinha uma visão diferente da de Fourier, pois considerava necessário combinar instrução (teórica e prática), trabalho produtivo e ginástica, numa perspectiva de educação integral, de acordo com as exigências da moderna produção fabril. Vinculava de forma integrada, atividades manuais e acadêmicas, contrapondo-se a todos que consideravam desnecessário ensinar cultura geral à classe trabalhadora operária (MACHADO, 1989, p. 51).

Esses elementos serão, mais tarde, incorporados nas concepções pedagógicas de Marx, como o próprio ressalta n'O Capital:

Do sistema fabril, como podemos ver detalhado na obra de Robert Owen, brota o germe da educação do futuro, que há de conjugar para todas as crianças a partir de certa idade, o trabalho produtivo com o ensino e a ginástica, não só como forma de incrementar a produção social, mas como único método para a produção de seres humanos desenvolvidos em suas múltiplas direções (MARX, 2013, p. 554).

As aproximações e distanciamentos entre as concepções de educação de Marx e Owen serão analisadas, de forma pormenorizada, mais adiante. Mas pode-se antecipar, no entanto, um ponto de divergência crucial: Owen, assim como Saint-Simon, acreditava que a educação poderia ser um elemento de eliminação das desigualdades, já que, como ressalta Machado, "de posse dos conhecimentos da cultura do seu tempo", os trabalhadores "poderiam influir sobre o meio e as circunstâncias, possibilitando uma reforma na sociedade" (MACHADO, 1989, p. 51).

Owen pôde, ao contrário de seus contemporâneos, tentar implementar suas concepções educacionais na prática. Em 1797, o industrial britânico adquiriu uma fábrica têxtil em New Lanark, na Escócia, com o objetivo de transformar a realidade dos trabalhadores ali empregados, passando aquela indústria a ser "um paraíso social, onde segurança no emprego, aumento substancial das horas de lazer e do salário, eliminação do trabalho infantil e instrução gratuita e integral aos filhos dos operários convivessem com a alta rentabilidade da empresa" (PIOZZI, 1999, p. 8). Essa transformação se daria a partir da reorganização do processo produtivo da fábrica, que passaria a ser ordenada a partir de pequenos conglomerados cooperativos.

A inovação do experimento de New Lanark estava não só na reorganização do processo produtivo, mas também na construção de um novo projeto político-pedagógico voltado para a formação dos filhos dos trabalhadores, baseado em três aspectos: (1) direito universal à infância - proibição do envolvimento das crianças em qualquer tipo de trabalho até os 12 anos $^{4}$-; (2) criação da infant school, combinado entre creche e pré-escola, como um espaço de livre expressão do imaginativo e do lúdico; e (3) "métodos de ensino baseados na observação de objetos concretos e visualizáveis, no lugar das usuais formas de memorização e de raciocínio abstrato e, sobretudo, no banimento de castigos e prêmios, em favor de uma troca afetiva entre alunos e professores" (PIOZZI, 1999, p. 10).

As experiências de Owen, apesar de pontuais e sem maiores repercussões nos sistemas de ensino tradicionais, formaram base para o início de reflexões críticas sobre a educação de base burguesa. Sem dúvida, a principal contribuição owenista seria a associação entre trabalho e instrução, construída a partir da crítica à concepção burguesa de politecnia. 
As críticas mais radicais às concepções de educação burguesa, em especial no que tange à educação politécnica, surgem a partir das contribuições dos ditos socialistas libertários, mais conhecidos como anarquistas. As contribuições de Pierre Joseph Proudhon, Mikhail Bakunin Paul Robin, Sébastien Faure e Célestin Freinet darão base para um novo entendimento do conceito de politecnia.

Assim como es alguns de seus companheiros utópicos, Proudhon constrói a sua concepção de educação a partir da crítica do capitalismo e da divisão social do trabalho. $\mathrm{O}$ anarquista francês acreditava que a educação burguesa tinha como objetivo primordial a manutenção de uma grande massa de trabalhadores sem acesso mínimo às condições de humanidade, tendo um caráter de educação servil e mantenedora da hegemonia burguesa. A perspectiva libertária de educação, defendida por Proudhon, está apoiada em dois pressupostos fundamentais: a educação integral e a educação para a liberdade.

A concepção de liberdade, para os anarquistas, tem uma perspectiva mais ampla do que as advindas do pensamento iluminista do século XVIII e do liberalismo. Proudhon e seus seguidores acreditam que a liberdade plena é um processo a ser construir, sob novas bases, e que superem as contradições impostas pelo capitalismo, como ressalta Silvio Gallo sobre as ideias do pensador libertário:

Só o homem completo em sua humanidade pode conquistar socialmente a sua liberdade; uma sociedade só pode ser igualmente livre através da igualdade dos indivíduos que a constroem por meio de relações solidárias, com a crescente liberdade de todos. (GALLO, 1995, p. 74)

Essa perspectiva está posta também na concepção de educação integral de base libertária, já que Proudhon defende a educação como um aspecto de superação e transformação da sociedade. Um elemento inovador desta perspectiva é a tentativa de superação também da divisão social do trabalho que impõe a dissociação entre o trabalho manual e intelectual, como salienta Gallo:

O cerne de toda a teoria pedagógica libertária é a ideia de educação integral. Essa discussão aparece muito cedo, e permeia todo o debate pedagógico entre os anarquistas, assumindo diferentes feições e interesses segundo os diferentes momentos históricos. A questão da educação politécnica (a rigor, o ensino de múltiplas técnicas) aparece nesse quadro da educação integral que consistiria, grosso modo, em educar o homem levando em consideração suas múltiplas facetas, que poderiam agrupar-se em três grandes dimensões: a físico, a intelectual e a moral (GALLO, 1993, p. 35).

Gallo qualifica essas três dimensões da seguinte forma: a dimensão intelectual diz respeito a apropriação de "toda a carga cultural produzida pela humanidade", dando ênfase às questões de base científica. A dimensão moral estaria relacionada a práticas de aprendizado que valorizassem os aspectos da solidariedade e da "construção comunitária da liberdade". Por fim, a dimensão física, que se daria em dois aspectos: o primeiro deles voltado para o "aprimoramento das percepções sensório-motoras", e o segundo aparece como a "educação manual” ou "educação profissional” (GALLO, 1993, p. 35).

Esse aspecto da educação pelo trabalho e para o trabalho, no entanto, não deveria acontecer desassociada das outras duas dimensões da educação integral: a moral e a intelectual. Além disso, os anarquistas defendem que a escola não deve ser um espaço para a profissionalização pura e simples, mas sim oferecer a possibilidade aos estudantes de vivenciar diversas formas de trabalho, através de inúmeras oficinas, que possibilitem o aprendizado de conhecimentos básicos úteis para diferentes profissões. Esses aspectos 
ficarão mais claramente entendidos durante as análises das experiências educacionais desenvolvidas por Robin e Faure.

Outro elemento valorizado na cultura pedagógica libertária é a democracia, expressa em dois âmbitos fundamentais: na democratização do acesso à educação, na promoção da igualdade de oportunidades, e na organização dos processos de ensinoaprendizagem, que não deve ser hierarquizado, através das práticas de autogestão. Esses elementos também ficarão mais evidentes através da análise das experiências de Robin e Faure.

Destacaremos, inicialmente, algumas proposições de caráter teórico-político relativos à vinculação entre trabalho e educação nas formulações teóricas de Proudhon. Como foi dito, a base da compreensão do socialista francês sobre essa vinculação está na crítica à divisão social do trabalho na sociedade capitalista que impõe uma dicotomia entre trabalho manual e intelectual. Gallo ressalta esse aspecto alienante do trabalho, mas também reforça aspectos positivos do fim da dissociação entre as dimensões intelectual e manual do trabalho:

Proudhon percebia que, na sociedade capitalista, uma das facetas da dominação era a dicotomia entre trabalho manual e trabalho intelectual: o trabalho intelectual, de planejamento, supervisão e gerencia é geralmente realizado pelos burgueses, enquanto que o trabalho manual, o trabalho cansativo, desgastante e, não raro, degradante e embrutecedor, este sim era realizado pelos operários. Entretanto, notava Proudhon, qualquer trabalho será mais gratificante para quem o realiza se o trabalhador dominar todas as fases do processo, da planificação até a realização prática da produção. Proudhon é um ferrenho adversário do trabalho alienado, paradigma do capitalismo, em que o trabalhador não domina o objeto que produz, por não o conhecer por inteiro (GALLO, 1993, p. 36)

A defesa da associação entre o trabalho intelectual, de planejamento e concepção, e manual, de execução e produção concreta, é a base da perspectiva de educação politécnica para Proudhon e seus companheiros socialistas libertários. A politecnia seria um dos pressupostos para a superação da alienação do trabalho. "Para Proudhon essa politecnia da aprendizagem traduz-se na união da aprendizagem com a educação, na instrução literária e científica com a instrução industrial", afirma Gallo (1993, p. 37).

Essa concepção de politecnia pressupõe uma transformação do espaço escolar, que seria transformado em "oficina-escola", onde o ensino dos conhecimentos teóricos deveria se materializar na realização de trabalhos de caráter prático. Além disso, deve o estudante de uma escola politécnica compreender a integralidade dos processos produtivos,

Isto porque a politecnia implica no domínio do conhecimento da multiplicidade da produção; é o oposto da divisão do trabalho, algo que aproxima as condições do trabalho industrial, mais complexo e estruturado, às condições do trabalho artesanal, mais simples, e por isso vivido de forma integral, não alienante. A politecnia pressupõe naturalmente a pluralidade do múltiplo, como domínio de uma realidade complexa, que será percebida não como dividida, mas como uma complexidade articulada e interdependente (GALLO, 1993, p. 37).

Como veremos, essa percepção de politecnia se aproxima muito da proposta por Marx e Engels. Mas há um elemento fundamental que os coloca em posições opostas: o papel do Estado na educação politécnica. Enquanto Marx e Engels defendem o Estado como o agente garantidor das políticas educativas, os anarquistas, e em especial Proudhon, 
argumentam que essas são responsabilidades do setor produtivo industrial, ou seja, a escola seria levada até as fábricas. Gallo analisa este aspecto:

Sem dúvida, esta seria uma radical transformação do sistema educacional que sairia da esfera do Estado ou da esfera privada de instituições comumente mantidas pela Igreja, passando para a inciativa públicoprivada das indústrias. Proposta que vai de encontro àquela que visa transformar a escola de instituição política - cujo objetivo seria semear a submissão e garantir a dominação - em organismo econômico que possibilite a igualdade e a extinção da exploração (GALLO, 1993, p. 38).

Percebe-se aqui que os socialistas libertários dão à escola um papel transformador da sociedade que não será compartilhado por Marx e pelos marxistas. Como veremos adiante, para os marxistas o que transforma é a prática política de oposição ao modo de produção capitalista. Outro limite do pensamento de Proudhon esteve na sua impossibilidade de prever os movimentos de transformação do processo produtivo, como destaca Gallo:

Homem de seu tempo, [Proudhon] encarnou em si mesmo as contradições de sua época, como já foi assinalado anteriormente. Embora fosse um visionário em alguns casos, em outros momentos é incapaz de aceitar o desenvolvimento, como na defesa que faz do trabalho manual. Sem conseguir vislumbrar as novas formas de organização que seriam possibilitadas pela mecanização da produção, acaba por defender uma certa "escravização" do trabalhador ao trabalho, contrariando seu próprio pensamento e pondo-se ao lado daqueles que combatia com veemência. Contemporâneos de Proudhon um pouco mais jovens, entretanto, percebiam essas questões e as desenvolveriam, como Marx ou Bakunin, por exemplo (GALLO, 1993, p. 40).

Paul Robin foi o primeiro socialista libertário a tentar viabilizar na prática as reflexões teóricas de cunho pedagógico propostas por Proudhon e outros anarquistas. A familiaridade com esses temas veio da militância em movimentos operários na França da segunda metade do século XIX. Além de atuar na formação política de trabalhadores, Robin dirigiu alguns jornais anarquistas e da imprensa literária, produzindo em alguns deles reflexões sobre educação. Seu trabalho foi reconhecido por Karl Marx, que o convidou a elaborar a moção sobre educação integral aprovada no Congresso de Bruxelas da Associação Internacional dos Trabalhadores (AIT), da qual também foi membro de seu Conselho Geral.

A atuação de Robin nos congressos da AIT foi bastante destacada, em especial, no que se refere a defesa da educação integral. Já em 1867, no Congresso de Laussane, Robin participa das primeiras discussões sobre o tema dentro da AIT. Essas discussões se aprofundam no ano seguinte, em Bruxelas, onde, juntamente com Bakunin, Robin será responsável pela defesa da concepção de educação integral, a partir das formulações de vários autores do campo libertário, dentre os quais Proudhon.

Durante os congressos da AIT, Bakunin e Robin formulam os princípios do que entendem como educação integral, a partir da crítica aos efeitos nocivos que a divisão social do trabalho impunha à educação de caráter burguês. Há nessa crítica, uma forte intenção de associar o trabalho intelectual ao manual em uma concepção educativa que associasse teoria e prática, como afirma o próprio Bakunin: "o ensino integral, ao lado do ensino científico ou teórico, deve compreender necessariamente o ensino industrial ou prático. Somente assim é que se formará o homem completo: o trabalhador que compreende e que sabe" (BAKUNIN apud MORIYÓN, 1989, p. 44). 
Bakunin defende a associação do trabalho com a educação, a partir da apropriação da moral humana do trabalho, que o anarquista russo contrapõe a moral divina.

A moral divina considera o trabalho como uma degradação e como um castigo; a moral humana vê nele a condição suprema da felicidade humana e da humana dignidade. A moral divina, necessariamente, desemboca numa política que só reconhece direitos aos que, por sua posição econômica privilegiada, podem viver sem trabalhar. A moral humana só atribui direitos as que trabalham; ela reconhece que só pelo trabalho é que o homem se torna homem (BAKUNIN apud MORIYÓN, 1989, p. 45).

Essa percepção humana do trabalho, destacada por Bakunin, aproxima as concepções anarquista e marxista de trabalho. Ao entender que o ser humano só se caracteriza como tal a partir da sua capacidade de transformação da natureza, ou seja, a partir do trabalho, o libertário concorda com a dimensão ontológica do trabalho defendida por Marx e seus seguidores.

Gallo (1993) afirma que Robin foi responsável por desenvolver a primeira experiência socialista libertária de educação calcada na concepção anarquista de politecnia, quando dirigiu o Orfanato Prévost, em Cempuis, na França, entre 1880 e $1884^{5}$. Robin defendia que a educação politécnica deveria ser a base da formação secundária dos estudantes que, antes disso, deveriam ter uma educação de caráter mais generalista, porém também apoiada no trabalho.

O esquema de formação do Orfanato Prévost previa uma primeira etapa, durante a primeira infância, na qual os estudantes eram apresentados ao mundo do trabalho através da manipulação de instrumentos básicos de aplicação profissional (tais quais termômetros, metros, lupas, lunetas, etc.) com o intuito de aprimorar as habilidades manuais e sensitivas. Após os dez anos de idade, os estudantes passariam ao trabalho nas oficinas.

A escola de Cempuis possuía uma granja completa e oficinas de sapataria, imprensa e encadernação, forja, carpintaria, costura e uma lavanderia. Quando passavam para a aprendizagem nas oficinas, os alunos tinham um período de noves horas diárias de estudo, assim divididas: cinco horas eram destinadas aos trabalhos manuais (sendo três horas na oficina e duas nos trabalhos coletivos); as outras quatro horas eram destinadas aos trabalhos escolares propriamente ditos, como as aulas teóricas (GALLO, 1993, p. 41).

Até os doze anos de idade, os estudantes de Prévost se envolviam nas atividades de oficina em um esquema e revezamento em que cada semana realizava um tipo de trabalho, sem distinção de gênero, trabalhando meninos e meninas conjuntamente atividades de agricultura, encadernação, costura, trabalho com madeira, com metais e serviços variados de manutenção e limpeza. Assim, nessa primeira fase de educação os alunos eram introduzidos no mundo de trabalho, sem determinar uma especialização, porém possibilitando que os mesmos pudessem vivenciar formas distintas de trabalho, ajudando no processo posterior de profissionalização.

Além disso, os aspectos de formação política e geral não eram esquecidos. Havia uma ampla vivência de coletivização do trabalho, o que estimulava o espírito de solidariedade e de democracia, postos em prática a partir de um regime de autogestão. Essa forma de organização do trabalho e do processo de ensino-aprendizagem era colocado em oposição com as formas capitalistas de trabalho, o que proporcionava uma formação política aos alunos. Esse aspecto de formação crítica da escola foi mal vista pela comunidade e pelas instâncias políticas, através de uma série de manifestações de 
adversários de Robin, que o acusavam de estabelecer um ensino de caráter dogmático. Essa perseguição culminou na destituição do educador anarquista do Orfanato de Prévost, em 1884.

Experiência similar se estabeleceu na comunidade-escola de "La Ruche" (em português "A Colmeia"), capitaneada por Sébastien Faure, que transformou uma chácara nas proximidades de Paris em uma instituição de ensino oferecia formação profissional a órfãos e filhos de operários da região, entre 1904 e 1917. O esquema de formação de "La Ruche" é explicado pelo próprio Faure:

Nossos meninos formam três grupos; os pequenos, os médios e os grandes. Os pequenos são aqueles que, ainda bem novos para se dedicarem a qualquer trabalho de aprendiz, não frequentam nenhuma oficina e distribuem o tempo entre as aulas, brinquedo e pequenos serviços domésticos que podem fazer: limpar, varrer, descascar legumes, etc.. Os médios são os aprendizes. Sua jornada metade ao estudo e metade ao trabalho braçal. Os grandes são os que, tendo terminado os estudos propriamente ditos e também pré-aprendizagem, entram na aprendizagem $^{6}$ (FAURE apud GALLO, 1993, p. 42).

Ao contrário do que acontecia na experiência de Prévost, em "La Ruche" os períodos de escolarização não eram determinados por idades pré-definidas, sendo os grupos de pequenos, médios e grandes definidos de acordo com o grau de desenvolvimento de cada estudante. A etapa final de formação profissional dava-se, geralmente, entre doze e treze anos de idade, já que no início do século XX já era bastante comum que crianças dessa idade estivessem inseridas no trabalho produtivo. A etapa chamada de préaprendizagem permitia, portanto, uma primeira vivência de trabalho, possibilitando aos estudantes uma integração com a coletividade e a aplicação prática dos conhecimentos adquiridos em salas de aula. Nessa etapa, também, havia a associação entre o trabalho manual e intelectual, a partir da integração entre teoria e prática em oficinas de carpintaria, forja, de roupas, costura e encadernação. Esta última oficina, segundo Gallo (1993, p. 43), Faure tinha especial apreço, já que ali eram preparados materiais educativos e de propaganda do movimento libertário. Além dessas oficinas, os estudantes também atuavam em trabalhos de manutenção e limpeza da escola, bem como na cozinha, através de uma organização do trabalho autogerida pelos estudantes.

"La Ruche" permitiu a integração entre diversas formas de trabalho (intelectual e manual), possibilitando a inserção desses estudantes no mundo do trabalho de forma menos traumática. Esse período de transição entre o fim da escolarização e a profissionalização, segundo Faure, era bastante difícil para a maior parte dos trabalhadores franceses que não tinham a possibilidade de passar por processos formativos com esse caráter. Infelizmente as atividades de "La Ruche" foram encerradas em 1917, devido a dificuldades materiais e financeiras.

Por fim, outra experiência implementada por um socialista libertário a ser analisada neste trabalho é a obra de Célestin Freinet. Segundo Jaques Bens (1998), Freinet tornou-se educador por ter tido uma experiência escolar tida pelo próprio como neutra: "A escola não me marcou nem para o bem nem para o mal. Já que decerto ela não podia marca-me para o bem, alegro-me que não me tenha marcado para o mal, que tenha sido neutra, que tenha passado como algo anônimo por meus dias de criança, como água que escorre sobre a argila ressecada" (BENS, 1998, p. IX), dizia ele. Essa pouca importância da escola na vida das famílias camponesas francesas do começo do século XX (entre as quais estava a família Freinet), devia-se a pouca vinculação dos processos educativos com a realidade concreta. Portanto, Freinet passa a militar como educador com o intuito "estabelecer e 
interpretar a dialética instaurada entre o comportamento psicológico das crianças e o meio social delas" (idem). Assim, o educador francês passa a se ocupar de refletir numa escola que materializasse em um espaço de ensino-aprendizagem baseado nas condições dos trabalhadores franceses.

Freinet atrelava a sua vivência de pedagogo à militância política, tendo se filiado ao Partido Comunista, durante os anos 1920 e, mais tarde, aderindo ao anarquismo.

Segundo Bens, a pedagogia de Freinet estava fundamentada em três grandes ideias. A primeira delas é a educação para o trabalho, já que para ele só o trabalho é realmente formador, por dois motivos:

Primeiro, porque propõe as motivações mais fortes para a aprendizagem. Segundo, porque as aquisições do trabalho é que serão mais úteis na vida social e profissional. Claro, convém equivocar sobre o sentido da palavra "trabalho", que Freinet se empenha muito em distinguir tanto das tarefas extenuantes quanto das atividades artificiais de diversão (BENS, 1998, p. $\mathrm{X})$.

A segunda grande ideia se refere ao desenvolvimento máximo das possibilidades de cada criança. E, por fim, a terceira está relacionada a necessidade de fazer que cada criança se sinta parte de uma coletividade. Este último aspecto, segundo Bens, é negligenciado por alguns adeptos da pedagogia de Freinet que ignoram os aspectos libertários e coletivistas de sua obra.

Apesar de ter sido acusado, por alguns detratores de sua pedagogia, de ter se dedicado apenas a educação para os privilegiados, Freinet dedicou-se a formular práticas pedagógicas que permitissem a emancipação do proletariado, escapando ao aburguesamento. Graças a sua ligação com o Partido Comunista Francês, Freinet teve a oportunidade de vivenciar o modelo educativo aplicado na União Soviética, onde esteve em 1925, e pôde relatar essa experiência em um artigo Un Mois chez les Enfants Russes(Um Mês entre as Crianças Russas), publicado em 1927.

Um ano depois, Freinet se estabelece na cidade de Saint-Paul-de-Vence, onde cria a Cooperativa de Ensino Laico (CEL), que chega a contar com mais de 1500 associados, onde fica até 1934, quando se demite ao se considerar perseguido pelo Ministro da Educação francês, que o transferiu para outra cidade. Durante os anos em Saint-Paul faz uma série de experimentações de práticas pedagógicas apoiadas no trabalho. Ao demitir-se do serviço público, inaugura a Escola Freinet, na colina de Pioulier, em Vence, com o apoio da Liga dos Pais Proletários. Será nessa escola que Freinet desenvolverá a base de sua pedagogia.

A Escola Freinet torna-se também o locusda sua militância contra o fascismo, tornando-se um asilo onde eram recebidas inúmeras crianças refugiadas da Espanha. Em, 1940, Freinet é preso pela polícia de Vichy, acusado de ser um militante comunista. A Escola Freinet permanece fechada durante todo o período da Segunda Grande Guerra, sendo reaberta em 1945. Após o fim da Guerra, Freinet divide-se entre a escola que recebeu seu nome e a CEL, que no início dos anos 1960 chega a reunir mais de trinta mil associados. Além disso, em 1961, funda a Federação Internacional dos Movimentos para a Escola Moderna (FIMEM). Após a sua morte, em 1966, a Escola Freinet passa a ser administrada por uma associação, cuja finalidade é assegurar a conservação, o desenvolvimento e a aplicação prática dos métodos pedagógicos elaborados educador francês. Em 1991, a Escola Freinet tornou-se uma escola pública ${ }^{7}$.

Os relatos dessas experiências pedagógicas dirigidas por Freinet encontram-se descritas em formato pouco acadêmico, que remete às crônicas do cotidiano das escolas. Há pouquíssima reflexão de caráter científico nas observações feitas pelo educador francês. 
No entanto, é possível levantar nesses relatos alguns elementos da sua prática pedagógica. Em um deles, intitulado "Uma Educação do Trabalho", Freinet descreve cuidadosamente os preparativos da comunidade escolar para a festa de São João. O texto, repleto de metáforas, além da poesia, traz todo o sentido de coletividade daquele espaço. Em um determinado texto, Freinet faz uma digressão sobre o caráter do trabalho que ali é empregado:

Imitemos a natureza. Não quero dizer, claro, que ela tenha disposto tudo
de propósito para nosso uso e prazer. Longe disso. Mas ela não é
monotonamente rabugenta e austera como no estudo e no trabalho da
escola. Em todos os lugares habitáveis da terra, ela oferece suas alegrias -
alegrias para os olhos, para os ouvidos e para o paladar - ou suas
promessas. Parece que nem o homem nem a criança poderiam viver sem
a floração desses benefícios que dão sentido aos seus dias. Não é dessa
uniformidade baça que vocês lhes oferecem em seus livros que os alunos
têm sede, mas de calor, de frio, de brilho, de choques, de gritos, de
cantos, de esforços... Eles são como uma corda cuja natureza é vibrar.
Vocês temem que ela se quebre e vão reduzindo as reações, amenizando
as coisas, controlando em demasia as transições inúteis (FREINET, 1998,
p. 155-156).

.Não é tarefa simples retirar de um texto repleto de poesia o sentido referencial político do trabalho que prega Freinet para a sua escola. Mas pode-se perceber claramente uma oposição entre um tipo de trabalho mais livre - associado metaforicamente à aleatoriedade da natureza - e um trabalho mais austero, rabugento e uniforme das escolas tradicionais. Freinet adere - e faz uma ode - a essa primeira forma de trabalho, tida como os movimentos da natureza. Talvez haja uma relação entre a ontologia do ser humano, do trabalho como definidor da essência dos homens e mulheres, mas esse não é apenas um exercício de interpretação. Há, certamente, uma reivindicação da espontaneidade da organização do trabalho dos alunos em contraposição à "uniformidade baça" dos livros e trabalho das escolas tradicionais.

Essa reivindicação fica mais evidente em um trecho posterior, onde há uma clara crítica aos "escoliastas":

Por não poderem mais voar, os escoliastas tentaram cortar as asas de suas vítimas. O mais triste é que tenham sido parcialmente bem-sucedidos, que tenham travado uma guerra quase sempre vitoriosa contra a atividade, a alegria, o ímpeto; que tenham persuadido os filhos do homem de que deveriam ser bem-comportados, comedidos, humildes e dóceis ao dever, que os tenham retido na beirada do ninho onde preparavam para levantar voo e lhes tenham desensinado, em nome de sua ciência, a audácia física e intelectual que tinham em sua natureza generosa (FREINET, 1998, p. 157).

Desse trecho é possível perceber uma clara crítica à escola de caráter burguês, que tenta docilizar o estudante para que esse se adeque ao mundo do trabalho capitalista, repleto de normas de conduta e organizações rígidas de comportamento. Há também, ao se citar a ciência, uma referência crítica às pedagogias de matriz positivista e a separação entre o trabalho físico e intelectual. A crítica está pautada na limitação à liberdade e condenação das limitações impostas pela educação burguesa de caráter dual. Essa crítica à influência das pedagogias burguesas, em especial, ao positivismo se repete ao longo do texto, como no trecho que se segue: “(...) não é a primeira vez que nos pedem um grande esforço, sacrifícios do amor-próprio, completa dedicação ao futuro da nação, em nome do 
ideal, do progresso, da razão ou da humanidade". Ele considera um erro a adesão dos educadores a essa perspectiva de educação, "já que supõe a morte do nosso idealismo e a evolução, para o funcionalismo, do sacerdócio ao qual tínhamos, acima de tudo tentado nos entregar" (p. 158-159).

O caráter da vinculação do trabalho e da educação, defendidos por Freinet, evidencia-se no mesmo texto, quando ele se refere à burocracia do governo francês que impõe uma reforma da educação pública baseadas nas concepções burguesas de educação:

(...) no dia em que a organização da escola, seu equipamento e o aprimoramento das técnicas permitirem uma atividade agradável, dinâmica e produtiva como nas fábricas modernas bem projetadas, o papel dos professores ficará consideravelmente simplificado e normalizado. (...) Não temam ser atraídos à força pela mecanização excessiva: a tarefa de vocês ainda será suficientemente cativante; não perderia nada de sua grandeza, pos a máquina humana ainda é tão misteriosa que durante longo tempo restarão muitos imponderáveis para regular, adaptações para prever e para realizar e pensamento vivo para ser introduzido no mecanismo dinâmico e flexível da nova organização (FREINET, 1998, p. 161).

Freinet, ao se referir ironicamente aos dirigentes do processo educativo na França, traz uma reflexão que ficou ausente nas observações de Proudhon: a questão das transformações no processo produtivo capitalista advinda das mudanças técnicas. Esse avanço na análise é facilmente entendido se observarmos os momentos históricos da produção intelectual de ambos: enquanto Proudhon escreve na primeira metade do século XIX, Freinet já observa todas as transformações introduzidas no processo produtivo advindas do taylorismo e do fordismo, já no século XX.

Ao mesmo tempo que critica, em tom de ironia, a função do Estado na condução das políticas educativas, Freinet defende a vinculação da educação ao trabalho, absorvendo na escola os processos produtivos que estão nas fábricas. As transformações do espaço escolar devem estar vinculadas também às mudanças nos métodos de ensino e das práticas pedagógicas. Além disso, há uma evidente capacidade do socialista francês em prever as mudanças que ocorreriam no momento da flexibilização da produção capitalista. Ele defende que as mudanças no processo produtivo deverão ser acompanhadas de um processo de transformação do sistema educacional, que deverá dar atenção, na formação dos trabalhadores, aos aspectos intelectuais da formação, ou seja o trabalho de preparação, de ordenação, de aprimoramento, que segundo Freinet, havia, até então sido negligenciado (FREINET, 1998, p. 162).

A crítica ao sistema de ensino de orientação burguesa, oferecido aos trabalhadores, segue:

Vocês dão uma aula aos alunos; impõem-lhes um trabalho e vêm verificar logo em seguida, com uma miopia de burocrata, o efeito produzido, como as crianças da cidade que enfiam na terra uma muda, regam-na apressadamente e vêm no dia seguinte ver se as frutas cresceram. Vocês gritam, intimidam, punem, porque suas palavras, seus raciocínios e suas demonstrações não acarretam uma mudança imediata no pensamento e na ação dos que os escutam. (FREINET, 1998, p. 165).

A crítica aqui expõe a contradição entre as formas de produção e as formas de formação. Freinet retoma a crítica inicial da disciplina forçada e da falta de liberdade de organização nas escolas. A contraposição é apresentada a essa forma de escola é a educação pelo trabalho, que segundo ele, deve obedecer ao natural, ao simples. 
Essas ideias se complementam a necessidade de dois elementos fundamentais na pedagogia de Freinet: o jogo e o trabalho. Ambos são importantes para o processo educativo e devem ser oferecidos aos estudantes de acordo com o seu nível de formação. A tenra infância deve ser a idade dos jogos e, conforme avança o processo educativo se introduz o trabalho à formação dos estudantes, de acordo com o desenvolvimento de cada um. O processo formativo culmina no instante em que o trabalho toma a maior parte do tempo, ou seja, alcança a etapa de profissionalização. Um fator primordial para a pedagogia do socialista libertário francês é que tanto o trabalho quanto o jogo devem motivar o educando: "se pensamos que é possível oferecer à criança atividades" - trabalho ou jogos - "que as empolguem e as mobilizem inteiramente, é esse o caminho que devemos tomar" (FREINET, 1998, p. 188). A pedagogia freinetiana é baseada na positividade do trabalho, ou seja, está posto para Freinet que o a educação pelo trabalho deve estar em contraposição ao trabalho alienado, assim como sugeriu Proudhon.

Organizemos o trabalho para que, desde cedo, a criança se familiarize com as suas obrigações, mas sinta também suas incomparáveis satisfações; que centralize gradualmente a sua vida nessa necessidade funcional; que sua natureza se incorpore a ele, a tal ponto que, apesar das solicitações, das perversões e das delícias ilusórias que lhe oferecerá a civilização, a criança sempre retorne, depois de seus erros, à única atividade substancial e redentora: $o$ trabalho (FREINET, 1998, p. 165).

Outro elemento fundamental da positividade do trabalho apresentada por Freinet está na questão do trabalho coletivo. Para ele, o trabalho realizado em coletivo cria um sentido de solidariedade, união e pertencimento social. Para Freinet, trabalho é união.

Além disso, a questão da indissociabilidade do trabalho manual e do trabalho intelectual é um dos elementos primordiais da pedagogia freinetiana. Ao contrário de Proudhon, que sobrevalorizava o trabalho manual, Freinet valorizava o trabalho em sua dimensão integral, para além das atividades de oficina, jardinagem, etc., porém sem criar hierarquias entre essas duas dimensões.

O trabalho é um todo: nele pode haver tanto um bom senso, inteligência, especulação útil e filosófica no cérebro do homem que constrói um muro quanto no de um cientista que pesquisa em seu laboratório. Só que cada um exerce suas funções segundo suas tendências e possibilidades e, num Estado bem organizado, todas elas teriam sua eminente nobreza (FREINET, 1998, p. 309).

Por fim, é importante ressaltar a dimensão política da educação pelo trabalho, muito pouco valorizada nas análises sobre Freinet. Como foi dito anteriormente, todo o trabalho de pedagogo exercido por ele esteve atrelado a sua militância política, inicialmente no Partido Comunista e, mais tarde, junto aos movimentos anarquistas. A educação pelo trabalho em Freinet é, portanto, uma das dimensões de um projeto societário que pretendia transformar as bases materiais da sociedade de seu tempo.

A educação pelo trabalho é mais do que uma educação comum pelo trabalho manual, mais do que pré-aprendizagem prematura; baseada na tradição, mas prudentemente impregnada pela ciência e pela mecânica contemporâneas, ela é ponto de partida para uma cultura cujo centro será o trabalho (FREINET, 1998, p. 315)

Portanto, pode-se concluir, a partir das contribuições teóricas e práticas de Proudhon, Bakunin, Robin, Faure e Freinet, que a concepção anarquista de politecnia traz em si um elemento revolucionário, crítico e que pretende a transformação da sociedade 
capitalista. A base constitutiva dessa concepção está apoiada nas perspectivas da educação integral formuladas, em especial por Proudhon e aprofundadas por Robin. Essa base integra as dimensões moral, intelectual e física, numa concepção de educação centrada no trabalho e na liberdade. Sendo assim, a proposta de educação politécnica, em sua matriz libertária, apresenta uma alternativa mais justa e igualitária do que a concepção burguesa de politecnia, já que a mesma não se restringe à manutenção do poder político-econômico de um grupo social específico. Por fim, deve-se ressaltar nessa concepção de politecnia a centralidade do trabalho como um elemento agregador, coletivista e solidário, baseados essencialmente nas práticas democráticas de autogestão.

Essas proposições terão grande influência na construção de um projeto políticopedagógico de toda a esquerda ocidental, em especial por terem ganho proeminência entre os membros da Associação Internacional dos Trabalhadores. Haverá apenas algumas poucas contestações por parte de Karl Marx e de outros marxistas sobre o papel do Estado na aplicação dessa concepção político-pedagógica. Em geral, existem, como veremos adiante, poucas discordâncias, podendo-se dizer, portanto, que foi do campo libertário e utópico que surgiu a base das pedagogias críticas, de matriz revolucionária, desenvolvidas a partir do século XVIII.

\section{A concepção marxiana-engeliana de educação politécnica}

Karl Marx e Friedrich Engels jamais se dedicaram a um estudo exclusivo sobre educação e, por isso, suas observações sobre os processos educativos aparecem de maneira esparsas em diversos trabalhos. Isso não quer dizer, no entanto, que os dois autores não tenham se preocupado com o tema. A recorrência dos temas em seus trabalhos evidencia essa preocupação. Esses elementos são suficientes, portanto, para a compreensão de alguns princípios pedagógicos fundamentais para Marx e Engels.

Há, no entanto, uma evidente absorção, por parte dos dois autores, de elementos pedagógicos de outras correntes de pensamento. Essa apreensão se dá, em especial, durante os debates nos congressos da Associação Internacional dos Trabalhadores. Isso se deve principalmente por terem os socialistas utópicos e libertários se dedicado de forma mais intensa aos estudos sobre educação.

Vários autores já se dedicaram a analisar os princípios pedagógicos na obra de Marx e Engels, porém dois deles se destacam: Mario Alighiero Manacorda e Bogdan Suchodolski. O primeiro deles, italiano, produziu uma obra que até hoje é referência para qualquer estudioso dos temas que relacionam marxismo e educação: Marx e a Pedagogia Moderna, publicado originalmente em 1986. Nessa obra, Manacorda faz uma análise de caráter filológico de como as reflexões de Marx sobre a educação aparecem em seus escritos, bem como a repercussão desse pensamento em outros autores marxistas. $\mathrm{O}$ segundo deles, polaco, escreveu um tratado em três volumes, intitulado Teoria Marxista da Educação, uma obra bastante profunda que não se limita apenas a analisar a abordagem de Marx e Engels sobre a educação, mas se remete ao caráter político da obra desses dois autores, o que permitiu a Suchodolski construir, a partir-desses referenciais elementos constitutivos de uma pedagogia marxiana-engeliana.

Além dessas obras, existem compêndios dos escritos de Marx e Engels sobre o tema da educação. O mais conhecido deles foi organizado por Roger Dangeville, recebeu o título de Crítica da Educação e do Ensino, sendo publicado em Paris, em 1976. No Brasil, trabalhos parecidos também foram publicados, sendo o mais completo, o coordenado por José Claudinei Lombardi, cuja edição mais recente, sob o título Textos sobre Educação e Ensino, foi publicada em 2011 (MARX; ENGELS, 2011). 
A partir da análise dessas obras é possível entender os elementos constitutivos da pedagogia marxiana que está conformada, basicamente, em três aspectos principais. $\mathrm{O}$ primeiro deles diz respeito à crítica aos preceitos da educação de caráter burguês, marcada pela divisão social do trabalho. É importante ressaltar que, para Marx e Engels, essa crítica transcende o aspecto da educação e está centrada, em especial, nos elementos políticoeconômicos do modo de produção capitalista, ou seja, a concepção de educação burguesa é marcada pelas contradições entre capital e trabalho.

O segundo aspecto está ligado à importância da apropriação dos conhecimentos, da cultura e da ciência por parte da burguesia. Marx e Engels nos dão elementos para compreender que esses aspectos funcionam, no processo produtivo, como meios de produção, mesmo sem serem meios materiais. Tal qual as terras, as máquinas, a energia, o espaço da fábrica; o conhecimento racional produzido e acumulado pela humanidade ao longo da história, também sofreram um processo de expropriação e, durante o processo de Revolução Industrial, são apropriados, tornando-se propriedade privada das classes dominantes. Esses conhecimentos são alienados da classe trabalhadora, que só tem acesso aos princípios básicos da ciência e do conhecimento racional, suficientes para que se possa executar sua função dentro do processo produtivo. Essa expropriação dos conhecimentos se deu a partir do aparelhamento da escola por parte da burguesia e da crescente divisão do processo de trabalho nas indústrias.

O terceiro, e último aspecto, diz respeito ao modelo educativo a ser defendido numa sociedade pós-capitalista. Marx e Engels, como veremos, defenderão uma educação que forme o ser humano em sua integralidade. Nesse aspecto, os autores originais do marxismo se apropriarão dos elementos constitutivos das concepções de educação dos socialistas utópicos e libertários, defendendo um ensino que articule o fazer e o pensar, a teoria e a prática, o ensino propedêutico e o trabalho. É importante ressaltar que esse modelo educacional seria inviável em uma sociedade marcada pela divisão social do trabalho, já que, no modo de produção capitalista, existe uma forte dissociação entre o trabalho manual e intelectual. Numa sociedade pós-capitalista, esses elementos seriam integrados, podendo os processos educativos caminhar para formação integral ou omnilateral de homens e mulheres.

Apesar de Marx e Engels se apropriarem de elementos das concepções de educação dos socialistas utópicos e libertários, ambos, ao longo de sua trajetória política, fizeram questão de se colocar em outro campo, diferenciando-se de seus companheiros. Essas diferenciações ficaram mais evidentes durante os congressos da Associação Internacional dos Trabalhadores, mas estão postas antes durante a produção dos autores originais do marxismo. O que aproximava Marx e Engels de seus companheiros utópicos e libertários era a crítica ao modo de produção capitalista e, o que os distanciava, era a forma como buscavam superá-lo. Enquanto os primeiros defendiam que essa superação deveria ser marcada por um processo político e econômico, os utópicos e libertários defendiam uma batalha ideológica, na qual a educação teria um papel redentor.

Para a superação do modo de produção capitalista, Engels e, principalmente, Marx desenvolveram uma crítica a economia política que tinha como objetivo fazer uma análise científica de como se estruturava os processos produtivos capitalismo e onde estavam suas contradições. A superação dessas contradições seria conquistada a partir de um processo revolucionário, posto em marcha pela classe trabalhadora.

Para a exposição dos elementos constitutivos da teoria marxiana-engeliana de educação, utilizaremos a clássica divisão sugerida por Manacorda (2010, p. 39-66) em Marx e Pedagogia Moderna, que marca o pensamento pedagógico de Marx e Engels em três momentos distintos: (I) o primeiro deles, entre 1847 e 1848, quando da produção por 
Engels dos Os Princípios do Comunismo (1847) e do Manifesto Comunista (1848), escrito em parceria com Marx. Em seguida, o (II) segundo momento, entre 1866 e 1867, quando Marx redige as Instruções aos delegados do Conselho Geral Provisório do I Congresso da Associação Internacional dos Trabalhadores, momento no qual também se dedicava à redação d'O Capital. E, por fim, o (III) terceiro momento, quando Marx produziu sua Crítica ao Programa de Gotha, em 1875.

Antes mesmo da produção d'Os Princípios do Comunismo e do Manifesto Comunista, Friedrich Engels já havia demonstrado preocupação com a questão da educação. Em A situação da classe trabalhadora na Inglaterra, de 1844, Engels demonstra a sua apreensão com as crianças e os jovens da classe trabalhadora que, já nas primeiras décadas do século XIX, desde muito cedo, dedicavam muitas horas dos seus dias ao trabalho produtivo nas fábricas. $\mathrm{O}$ autor denuncia que essa condição era extremamente prejudicial ao processo formativo desses jovens, já que os mesmos estavam submetidos a exaustivas jornadas de mais de dez horas de trabalho e, após isso, frequentavam escolas noturnas com instalações precárias e professores pouco preparados. A falta de educação das classes trabalhadora é um elemento muito ressaltado na primeira obra de fôlego de Engels. Além disso, ele advertia para as contradições dos modelos educativos de origem burguesa e das escolas nas quais os operários e seus filhos eram obrigados a se educar: "nessas instituições, toda a educação é domesticada, dócil e servil diante da política e da religião dominantes; seu objetivo, por meio de prédicas constantes, é tornar o operário obediente, passivo e resignado diante de seu destino" (ENGELS, 2010, p. 272).

Engels ressalta que a educação burguesa era de tal maneira inócua que, já em meados do século XIX, uma quantidade cada vez maior de operários se aproximava dos movimentos operários não só para sua organização política e reivindicação de melhores condições de vida e de trabalho, mas também para buscar novas formas de se educar. Nesse ponto da análise, ele paga tributo às experiências de educação dos socialistas e cartistas:

Todas as organizações socialistas, quase todas as cartistas e muitas associações profissionais possuem instituições desse gênero; nas escolas, oferece-se às crianças uma educação verdadeiramente proletária, livre das influências burguesas, e nos salões de leitura encontram-se quase exclusivamente livros e jornais proletários (ENGELS, 2010, p. 271)

Engels ressalta, ainda, que nesses círculos de leitura e educação operária, circulavam uma série de obras de formação política, entre as quais, clássicos do pensamento anarquistas:

Especialmente os socialistas, nesse domínio, contribuíram vigorosamente para a educação do proletariado, traduzindo e divulgando os materialistas franceses - Helvétius, d'Holbach, Diderot etc. - em edições a preço económico, ao lado dos melhores autores ingleses; também circulam apenas entre os proletários a Vida de Jesus, de Strauss, e a Propriedade, de Proudhon. Shelley, o genial e profético Shelley, e Byron, com seu ardor sensual e sua amarga crítica à sociedade atual, contam a maioria de seus leitores entre os operários - os burgueses só recorrem a edições expurgadas, as familyeditions [edições familiares], modificadas ao gosto da hipócrita moral vigente. Os dois maiores filósofos práticos mais contemporâneos, Bentham e Godwin (especialmente este) são património quase exclusivo do proletariado - embora Bentham tenha seguidores na burguesia radical, só o proletariado e os socialistas extraíram dele elementos progressistas. Sobre essas bases, o proletariado criou uma literatura própria, constituída sobretudo por opúsculos e jornais e cujo 
conteúdo supera largamente a literatura burguesa (ENGELS, 2010, p. 273).

Apesar de Engels não citar diretamente as organizações socialistas utópicas e libertárias, a citação desses autores, cuja leitura era amplamente difundida entre esses socialistas em meados do século XIX, nos dá elementos para inferir essa referência indireta. Esse aspecto reforça a tese de que as concepções educativas de Marx e Engels sofreram influências dos socialistas "não-científicos".

A análise de Engels sobre a educação da classe trabalhadora aparece também na crítica ao uso do trabalho infantil nas fábricas. Ideias similares são possíveis de se notar em Princípios Básicos do Comunismo (1847), onde ele defende: "educação de todas as crianças, a partir do momento em que podem passar sem os cuidados maternos, em estabelecimentos nacionais e a expensas do Estado", e combinação entre "a educação e o trabalho fabril" (ENGELS, $2006^{8}$ ).

Nesse mesmo texto, aparece a preocupação de Engels com a formação integral dos trabalhadores, já que, segundo ele, a divisão do trabalho imposta pelo modo de produção capitalista, acaba por fragmentar a formação:

\begin{abstract}
A divisão do trabalho, minada já hoje pelas máquinas, que faz de um camponês, do outro sapateiro, do terceiro operário fabril, do quarto especulador de bolsa, desaparecerá, portanto, totalmente. A educação permitirá aos jovens passar rapidamente por todo o sistema de produção; colocá-los-á em condições de passar sucessivamente de um ramo de produção para outro, conforme o proporcionem as necessidades da sociedade ou as suas próprias inclinações. Retirar-lhes-á, portanto, o carácter unilateral que a actual divisão do trabalho impõe a cada um deles. Deste modo, a sociedade organizada numa base comunista dará aos seus membros oportunidade de porem em acção, integralmente, as suas aptidões integralmente desenvolvidas (ENGELS, 2006 - grifo meu).
\end{abstract}

É importante notar que os pressupostos da educação para os trabalhadores, defendidos por Engels, são formulados a partir da crítica da realidade imposta pelo modo de produção capitalista daquele momento histórico. A partir dessa crítica, o autor desenvolve ideias de como deveria ser a educação para os trabalhadores em futura sociedade, na qual, a divisão social do trabalho não faria parte da realidade. Isso fica evidente no trecho supracitado e no seguinte, quando defende que nessa sociedade comunista haverá: "o desenvolvimento onilateral das capacidades de todos os membros da sociedade, mediante a eliminação da divisão do trabalho até agora existente, mediante o ensino industrial ${ }^{9}$, mediante o alternar-se das atividades (...)" (ENGELS, 2006).

Já no Manifesto Comunista, Marx e Engels defenderão a "educação pública e gratuita a todas as crianças; abolição do trabalho das crianças nas fábricas, tal como é praticado hoje" e a "combinação da educação com a produção material" (MARX; ENGELS, 2010, p. 58). Esses três aspectos aparecerão recorrentemente na obra de Marx e Engels quando eles tratarem do tema da educação. O primeiro deles, diz respeito a universalização da educação, rompendo com as barreiras classistas impostas pelo modo de produção capitalista. Como veremos o segundo aspecto, sobre a abolição do trabalho infantil nas fábricas, será alterado em textos subsequentes, mas segue sendo sempre abordado. Já o terceiro, a associação de educação e trabalho, constituirá uma das bases da pedagogia marxiana-engeliana.

Essas ideias serão retomadas, por exemplo, nas Instruções aos Delegados para o I Congresso Internacional dos Trabalhadores. Algumas dessas ideias, no entanto, vão apresentar transformações. Isso fica claro, no que se refere à defesa da "abolição do 
trabalho infantil". Há uma inflexão no que tange esse tema, especialmente a partir de 1866, quando Marx escreve as Instruções. A partir daí, nota-se que já não há a defesa da "eliminação do trabalho das crianças nas fábricas", mas a aceitação do mesmo, desde que combinado ao processo educativo, como se poder ler no trecho:

O operário não é um agente livre. Em demasiados casos, ele é até demasiado ignorante para compreender o verdadeiro interesse do seu filho, ou as condições normais do desenvolvimento humano. No entanto, a parte mais esclarecida da classe operária compreende inteiramente que o futuro da sua classe, e, por conseguinte, da humanidade, depende completamente da formação da geração operária nascente. Eles sabem, antes de tudo o mais, que as crianças e os jovens trabalhadores têm de ser salvos dos efeitos esmagadores do presente sistema. [...] Partindo deste ponto, dizemos que nenhum pai nem nenhum patrão deveria ser autorizado a usar trabalho juvenil, excepto quando combinado com educação (MARX, $2008^{10}$ - grifo meu).

Tão importante quanto notar a mudança na avaliação de Marx e Engels sobre a questão do trabalho infantil é entendê-la historicamente. Pode-se perceber que ela aparece como forma de garantir às crianças e aos jovens trabalhadores um trabalho que pudesse ter efetivo caráter formativo e educativo. Entre meados do século XIX o trabalho infantil era uma realidade difícil de ser revertida de imediato e, por isso, Marx passa a assumir que era necessário associar aquele trabalho, admitido como puramente exploratório, como algo que pudesse contribuir para a educação das crianças empregadas nas fábricas. A combinação do trabalho na fábrica com o processo formativo aparece como uma alternativa para o trabalho infantil. Manacorda ressalta que Marx proporá uma subdivisão das crianças, para fins de trabalhos em três grupos etários: "dos 9 aos 12, dos 13 aos 15 e dos 16 aos 17 anos" "com horários diários, respectivamente, de 2, 4 e 6 horas", combinando esse trabalho atividades formativas (MANACORDA, 2010, p. 48).

Marx defende sua concepção de educação no seguinte trecho das Instruções:

Por educação entendemos três coisas:

1) Educação intelectual.

2) Educação corporal, tal como a que se consegue com os exercícios de ginástica e militares.

3) Educação tecnológica, que recolhe os princípios gerais e de caráter científico de todo o processo de produção e, ao mesmo tempo, inicia as crianças e os adolescentes no manejo de ferramentas elementares dos diversos ramos industriais.

À divisão das crianças e adolescentes em três categorias, de nove a dezoito anos, deve corresponder um curso graduado e progressivo para sua educação intelectual, corporal e politécnica. Os gastos com tais escolas politécnicas serão parcialmente cobertos com a venda de seus próprios produtos.

Esta combinação de trabalho produtivo pago com a educação intelectual, os exercícios corporais e a formação politécnica elevará a classe operária acima dos níveis das classes burguesa e aristocrática.

$\mathrm{O}$ emprego de crianças e adolescentes de nove a dezoito anos em trabalhos noturnos ou em indústrias, cujos efeitos sejam nocivos à saúde deve ser severamente proibido por lei (MARX, 2011, p. 85-86).

Há muitos elementos para análise no trecho supracitado. Esta definição é, sem dúvida, a mais elaborada consideração de Marx sobre educação em sua obra. No trecho é possível ter uma noção mais clara do que ele entende como relação entre trabalho e 
educação, na qual se percebe a importância da vinculação entre as questões relativas a associação da educação pelo e para o trabalho manual e o trabalho intelectual.

Além das Instruções, entre 1866 e 1867, no que Manacorda convencionou tratar como segundo momento das reflexões marxianas sobre educação, há a produção d' $O$ Capital. As ponderações ali contidas pouco se diferenciam das expostas nas Instruções, no entanto, como trata-se de uma obra mais densa, Marx pode aprofundar um pouco suas ideias sobre educação. No capítulo 13 de sua principal obra, ele faz uma análise sobre as legislações fabris de meados do século XIX, traz críticas ao modelo educativo vigente na Inglaterra e apontas novas perspectivas. Em um dos trechos, já citados nesse capítulo, Marx remete a Owen o pioneirismo de perceber como a conjugação de "trabalho produtivo com ensino e a ginástica" seria o germe para uma "educação do futuro" (MARX, 2013, p. 554). Mais adiante, Marx descreve alguns elementos práticos da produção capitalista que dão margem a sua subversão do próprio sistema e dá o exemplo das escolas de ensino profissionalizante:

Uma fase desse processo de revolucionamento, constituída espontaneamente com base na grande indústria, é formada pelas escolas politécnicas e agronômicas, e outras pelas écoles d'enseignement professionnel [escolas profissionalizantes], em que filhos de trabalhadores recebem alguma instrução sobre tecnologia e manuseio prático de diversos instrumentos da produção. Se a legislação fabril, essa primeira concessão penosamente arrancada ao capital, não vai além de conjugar o ensino fundamental com o trabalho fabril, não resta dúvida de que a inevitável conquista do poder político pela classe trabalhadora garantirá ao ensino teórico e prático da tecnologia seu devido lugar nas escolas operárias (MARX, 2013, p. 558).

Como já foi ressaltado, as escolas politécnicas que Marx aqui faz menção certamente não estão entre as grandes écoles francesas. Ao invés das escolas de nível superior, Marx faz menção as escolas de educação profissional voltadas para a classe trabalhadora. Ele via alguma virtude na débil, porém existente, vinculação entre formação enciclopédica (fundamental) com o trabalho fabril, mas reforça que as escolas operárias (do futuro) deverão reforçar esse aspecto.

Por fim, o derradeiro momento da obra de Marx e Engels no qual se dá destaque aos temas educacionais ocorre em 1875, quando Marx envia um texto aos participantes do Congresso acontecido na cidade alemã de Gotha, em maio daquele ano, quando houve a unificação do Partido Operário Social-Democrata e da Associação Geral dos Trabalhadores Alemães em uma nova organização, o Partido Operário Socialista da Alemanha. O texto, originalmente intitulado de Glosas Marginais ao Programa do Partido Operário Alemão, que viria a ser conhecido mais comumente como Crítica ao Programa de Gotha, traz apontamentos críticos a vários pontos do programa. O esboço do programa, que Marx teve acesso, trazia entre as exigências do Partido Operário Alemão, "como base espiritual e moral do Estado" dois pontos, sendo o primeiro deles "Educação popular e universal e igual, sob incumbência do Estado. Escolarização universal obrigatória. Instrução gratuita" ". Marx inicia sua crítica tecendo suas considerações sobre a questão da educação popular igual:

Educação popular igual? O que se entende por essas palavras? Crê-se que na sociedade atual (e apenas ela está em questão aqui) a educação possa ser igual para todas as classes? Ou se exige que as classes altas também devam ser forçadamente reduzidas à módica educação da escola pública, 
a única compatível com as condições econômicas não só do trabalhador assalariado, mas também do camponês? (MARX, 2012, p. 45).

A crítica de Marx centra-se, ao mesmo tempo, no caráter desigual imposto dela divisão classista da educação, no modo de produção capitalista, e a falta de um projeto educacional para a classe trabalhadora no Programa. E então, segue sua crítica sobre questão da universalização obrigatória e da gratuidade da instrução:

"Escolarização universal obrigatória. Instrução gratuita." A primeira existe na Alemanha, a segunda na Suíça [e] nos Estados Unidos, para escolas públicas. Que em alguns estados deste último também sejam "gratuitas" as instituições de ensino "superior" significa apenas, na verdade, que nesses lugares os custos da educação das classes altas são cobertos pelo fundo geral dos impostos. O mesmo vale, diga-se de passagem, para a "assistência jurídica gratuita" exigida no artigo 5. A justiça criminal é gratuita em toda parte; a justiça civil gira quase exclusivamente em torno de conflitos de propriedade, dizendo respeito, portanto, quase exclusivamente às classes proprietárias. Elas devem mover seus processos à custa do tesouro público?

O parágrafo sobre as escolas devia ao menos ter exigido escolas técnicas (teóricas e práticas) combinadas com a escola pública.

Absolutamente condenável é uma "educação popular sob incumbência do Estado". Uma coisa é estabelecer, por uma lei geral, os recursos das escolas públicas, a qualificação do pessoal docente, os currículos etc. e, como ocorre nos Estados Unidos, controlar a execução dessas prescrições legais por meio de inspetores estatais, outra muito diferente é conferir ao Estado o papel de educador do povo! O governo e a Igreja devem antes ser excluídos de qualquer influência sobre a escola. No Império prussiano-alemão (e não se escapa da questão com o cômodo subterfúgio de que se trata de um "Estado futuro"; já vimos no que este consiste), é o Estado que, ao contrário, necessita receber do povo uma educação muito rigorosa (MARX, 2012, p. 45-46).

A questão do papel do Estado na educação parece sofrer alguma inflexão nas reflexões de Marx. Mas o fato é que Marx repele a influência do Estado burguês na educação. A proposta de gestão das escolas teria como inspiração as organizações formadas durante a Comuna de Paris, num sistema "não burocrático, com a intervenção direta da população trabalhadora através de seus delegados e num marco de democracia direta" (MARX; ENGELS, 2011, p. 19). Esse aspecto é reforçado pela análise de José Claudinei Lombardi (2008):

As intervenções de Marx eram no sentido favorável a uma educação que, sendo pública e gratuita, também fosse livre e laica. Essas observações ganham corpo nas reflexões de Marx sobre a Comuna de Paris, no fim da guerra franco-prussiana de 1870-1871, em que ficam reafirmadas suas posições ante as medidas colocadas em prática pelos comunards(LOMBARDI, 2008, p. 17).

\section{Considerações finais}

Portanto, podemos, através da análise aqui proposta, delimitar os principais elementos da pedagogia alvitrada por Marx e Engels: o primeiro aspecto, talvez o central entre eles, está na centralidade do trabalho como elemento formativo e da vinculação entre os aspectos do processo produtivo e o ensino. A partir da crítica da divisão do trabalho imposta pelo modo de produção capitalista, Marx e Engels reforçam a necessidade de 
associação entre os trabalhos intelectual e manual nos processos educativos. Esse aspecto, associado à educação física, viabilizaria uma educação de caráter onilateral, ou seja, integral, à classe trabalhadora.

A centralidade no trabalho, através da associação entre teoria e prática, formulou a base do que se compreende a concepção de educação politécnica de base marxianaengeliana. Esse aspecto é comumente reforçado por autores como Dermeval Saviani. Esses princípios compõem o que se convencionou chamar, de educação politécnica, ou simplesmente politecnia. Aqui, politecnia assume uma concepção muito mais ampla do que a polissemia da palavra - várias técnicas - nos indica. Há um sentido político, nessa ideia da educação politécnica que, segundo ressalta Saviani, diz respeito "ao domínio dos fundamentos científicos das diferentes técnicas que caracterizam o processo de trabalho moderno" (SAVIANI, 2003, p. 140). Essa proposta de educação permitiria acesso da classe trabalhadora aos conhecimentos historicamente acumulados, apropriados pela burguesia como meios de produção (Saviani, 2003, p. 149). Além disso, a associação do processo educativo à produção proporcionaria aos trabalhadores uma formação integral (omnilateral) já que permitiria a estes uma compreensão mais global do processo produtivo.

No entanto, não se pode assumir essa concepção de educação sem considerar um horizonte de transformação mais amplo do modo de produção. A potencialidade da proposta de educação que vinculada ao trabalho é deveras reduzida em uma sociedade baseada na divisão social do trabalho e na estratificação social que opõe os proprietários dos meios de produção e os expropriados. Portanto, a proposta educativa marxiana não pode ser considerada sem estar intimamente associada a um projeto de transformação da sociedade que preveja a substituição do modo de produção capitalista por uma forma de organização da produção na qual os meios de produção estejam controlados pela classe trabalhadora.

Gaudêncio Frigotto nos ajuda a compreender a essência dessa concepção educativa:

Tornando-se, então, as relações sociais de trabalho, mediante as quais os homens produzem sua existência, e o trabalho, enquanto tal, como princípio educativo, a análise da escola que se articula com os interesses da classe que tem seu trabalho alienado, expropriado, não passa pela separação entre escola e trabalho, mas se situa na apreensão da "escola do trabalho", como nos é posta dentro da evolução da concepção marxista de escola politécnica (FRIGOTTO, 2010, p. 209-210).

Portanto, não se pode entender o projeto educativo proposto pelos autores originais dissociado do seu projeto societário. Da mesma forma que é necessário, para Marx e Engels, superar as contradições impostas pelo capitalismo, é preciso também superar as suas propostas pedagógicas, como ressalta Lucília Machado:

Os objetivos da escola única do trabalho e do ensino politécnico, como forma de sua realização, apontam a perspectiva da luta, cujos desdobramentos dependem das várias mediações necessárias a cada realidade concreta, historicamente determinada. Para superar o modelo liberal de escola unificada não é suficiente negá-lo. [...] o desenvolvimento de uma nova forma implica o esgotamento da antiga, fazer exaurir todas as suas energias, o que se obtém pelo desenvolvimento máximo das contradições existentes. Essa perspectiva de superação implica, portanto, passar, também, pelo modelo liberal de escola unificada, não como objetivo final da luta, mas como forma de acirramento das contradições, de maneira a preparar terreno para o 
amadurecimento das condições de desenvolvimento de uma escola radicalmente diferente (MACHADO, 1989, p. 130).

Talvez esteja nesse elemento, o da luta pela transformação da sociedade, a maior potencialidade da concepção de educação politécnica formulada por Marx e Engels. $\mathrm{O}$ potencial transformador das consciências, trazidas pela vinculação entre trabalho e educação. Esse aspecto pode trazer a luta uma série de indivíduos que ao perceber sua posição no processo produtivo, engaja-se na luta por revolucioná-lo.

Ademais, é possível perceber que a concepção de educação politécnica proposta por Marx e Engels sintetiza diversos elementos das elaborações anteriores feitas por socialistas utópicos e anarquistas. Os elementos que unificam as três concepções - utópica, libertária e científica - se referem à crítica da divisão social do trabalho, e suas consequências na educação, e à associação entre ensino e trabalho produtivo. No entanto, diferenças nos projetos societários de cada um desses grupos têm impacto nas distintas incorporações de elementos em cada uma das propostas pedagógicas. Talvez a principal diferença entre as propostas de educação politécnica de socialistas utópicos, anarquistas e científicos esteja no caráter redentor atribuído à educação pelos dois primeiros grupos. Ambos defendem que a educação da classe trabalhadora, trará elementos para a sua emancipação. Já os socialistas científicos acreditam que a emancipação é fruto da luta política e que é pouco provável que modelos educativos que questionem o meio de produção capitalista sejam viáveis sob as condições de exploração impostas.

Ainda assim, o próprio Marx, n'O Capital, cita as contribuições de socialistas utópicos, Robert Owen, pelo pioneirismo de associar a instrução ao processo produtivo (MARX, 2013, p. 554). Os socialistas libertários complexificaram a questão ressaltando o caráter positivo e formador do trabalho, que por sua vez caracteriza a própria essência do homem enquanto espécie. Essa ideia, ressaltada pelos anarquistas, aproxima-se muito da dimensão ontológica do trabalho descrita por Marx e Engels, que possibilitam ver o caráter educativo do trabalho enquanto ação humana em contraponto a dimensão histórica da época capitalista, onde o trabalho é alienado.

Devido à grande importância dos anarquistas durante a I Internacional (AIT) nos debates sobre a educação, nota-se que boa parte das concepções educativas levantadas pelos libertários foram incorporadas por Marx e Engels. A questão que os difere em suas concepções educativas é exatamente a que diferencia em seus projetos societários: o papel do Estado na educação. Enquanto os científicos acreditam que a tomada do Estado por parte dos trabalhadores é fundamental para estabelecer os elementos da sociedade comunista, anarquistas defendem que o Estado moderno é um instrumento burguês de dominação que deve ser extinto.

\section{Referências}

ARAUJO, José C. "O Embate Marxiano com a Construção dos Sistemas Educacionais. In: LOMBARDI, José. C. e SAVIANI, Dermeval. (orgs.). Marxismo e Educação. Campinas: Autores Associados/HISTEDBR, 2008.

BAKHTIN, Mikhail. Marxismo e Filosofia da Linguagem. São Paulo: Hucitec, 2006

BEMVINDO, Vitor. Por uma História da Educação Politécnica: Concepções, Experiências e Perspectivas. Niterói: UFF, 2016. Tese (Doutorado em Educação) Programa de Pós-Graduação em Educação, Faculdade de Educação, Universidade Federal Fluminense, Niterói, 2016. 
BENS, Jaques. "Abrir a Escola para a Vida". In: FREINET, Célestin. A Educação do Trabalho. São Paulo: Martins Fontes, 1998.

DIAS, Bruno C. "EPSJV: Trinta anos de um projeto transformador". Rio de Janeiro: Abrasco. 19 de agosto de 2015. Disponível em https://www.abrasco.org.br/site/2015/08/epsjv_30anos/. Acesso em 14/01/2016.

DÍAZ, Alexander. "El modelo de formación del profesional de nivel medio. Transformaciones actuales". In: Memorias de Pedagogía 2013. Havana: Educación Cubana, 2013.

ELÍSIO, Octávio. "Projeto de lei n. ${ }^{\circ}$ 1.258/88". In: GARCIA, Walter (coord.). Politecnia no Ensino Médio. São Paulo: Cortez Editora, 1991.

ENGELS, Friedrich. Princípios Básicos do Comunismo. Lisboa: Editorial Avante. 2006.

ENGELS, Friedrich. A Situação da Classe Trabalhadora na Inglaterra. São Paulo: Boitempo, 2010.

FREINET, Célestin. A Educação do Trabalho. São Paulo: Martins Fontes, 1998.

FRIGOTTO, Gaudêncio. A produtividade da escola improdutiva: um (re)exame das relações entre educação e estrutura econômico-social capitalista. São Paulo: Cortez Editora, 2010.

GALLO, Sílvio. "Politecnia e Educação: A Contribuição Anarquista". In: Pro-Posições. Campinas: Editora da Unicamp, 1993. v. 4. n. 3.

GALLO, Sílvio. Educação Anarquista: Um Paradigma para Hoje. Piracicaba: Unimep, 1995

LOMBARDI, J. C. "Educação, Ensino e Formação Profissional em Marx e Engels". In: LOMBARDI, José. C. e SAVIANI, Dermeval. (orgs.). Marxismo e Educação. Campinas: Autores Associados/HISTEDBR, 2008.

MACHADO, Lucília. Politecnia, escola unitária e trabalho. São Paulo: Cortez / Autores Associados, 1989.

MANACORDA, Mario A. Marx e a Pedagogia Moderna. $2^{\mathrm{a}}$ ed. Campinas: Editora Alínea, 2010.

MARX, Karl. Crítica do Programa de Gotha. São Paulo: Boitempo, 2012.

MARX, Karl. O Capital: Crítica da economia política. Livro I. São Paulo: Boitempo, 2013.

MARX, Karl; ENGELS, Friedrich. Manifesto Comunista. São Paulo: Boitempo, 2010.

MARX, Karl; ENGELS, Friedrich. Textos sobre Educação e ensino. Campinas: Navegando, 2011. 
MORIYÓN, Félix Garcia (Org.). Educação Libertária. Porto Alegre: Artes médicas, 1989.

NEVES, Lúcia. "Brasil Século XXI: Propostas Educacionais em Disputa". In: LOMBARDI, José C.; SANFELICE, José L. Liberalismo e Educação em Debate. Campinas: Autores Associados, Histedbr, 2007.

PIOZZI, Patrízia. "Robert Owen em New Lanark: um laboratório do futuro?". In: ProPosições, Campinas: Unicamp, v. 10, n.1 [28], 1999.

RODRIGUES, José. "Educação Politécnica". In: PEREIRA, Isabel; LIMA, Júlio. Dicionário da Educação Profissional em Saúde. Rio de Janeiro: FioCruz, 2009.

SAVIANI, Dermeval. “O choque teórico da politecnia”. In: Trabalho, Educação e Saúde, Rio de Janeiro, FIOCRUZ/EPSJV, v. 1, n.1, mar., 2003.

\footnotetext{
${ }^{1}$ Doutor em Educação pela Universidade Federal Fluminense. Foi coordenador pedagógico e professor do Instituto Politécnico da Universidade Federal do Rio de Janeiro em Cabo Frio entre 2010 e 2016 e membro do Grupo These.Instituto Politécnico da UFRJ em Cabo Frio. vitorbemvindo@yahoo.com.br
}

${ }^{2}$ A École Polytechnique é fundada com o nome de École Centrale des Travaux Publiques.

${ }^{3}$ Claude-Henri de Rouvroy, Conde de Saint-Simon (1760-1825).

${ }^{4}$ A idade mínima para o envolvimento no trabalho em New Lamark era inicialmente de 10 anos, sendo mais tarde alterada para os 12 anos.

${ }^{5}$ As primeiras elaborações de Paul Robin sobre a educação integral surgiram de sua experiência no Liceu de Brest, entre 1861 e 1864. Essa experiência não será abordada, já que não existem registros suficientes para a análise.

${ }^{6}$ Esse período de aprendizagem refere-se à educação profissional especializada.

${ }^{7}$ Os dados biográficos de CélestinFreinet foram obtidos na cronologia contida em "Referências Biográficas" In: FREINET, Célestin. A Educação do Trabalho. São Paulo: Editora Martins Fontes, 1998. (p. XV-XXIII).

${ }^{8}$ Documento eletrônico sem paginação. O trecho citado encontra-se na resposta para a $18^{\mathrm{a}}$ pergunta: "Que curso de desenvolvimento tomará essa revolução?”.

9 Sobre a questão do ensino industrial, Manacorda aponta que foi sobre essa denominação que Engels defendera a união de ensino e trabalho produtivo. Manacorda afirma que o ensino industrial tem um caráter "utópico e reformista", dado pela apropriação deste termo pela burguesia que teria como prática a alternância dos operários nos postos de trabalho. Antes de ter um caráter formativo e de compreensão integral do processo produtivo, esta forma de organização da dinâmica da produção está mais em concordância com as práticas de exploração do trabalho (Manacorda, 2010, p. 42-43). Essa denominação de "ensino industrial”, no entanto, será mais tarde refutada por Engels, juntamente com Marx, no Manifesto Comunista, 1848.

${ }^{10}$ Documento eletrônico sem paginação. O trecho citado encontra-se no item 4: "Trabalho juvenil e infantil (ambos os sexos)".

11 "Programa de Gotha (esboço)" In: MARX, 2012, p. 86-88. Nota do tradutor contida na edição: "Elaborado no pré-Congresso de Gotha, ocorrido entre 14 e 15 de fevereiro de 1875. É a versão que Marx tinha em mãos quando elaborou sua crítica".

Recebido: Fevereiro/2017. Aprovado: Abril/2017. 